\title{
Palestinian Women Contesting Power in Chaos
}

\author{
Islah Jad
}

Abstract Palestinian women's political participation is marked by the Israeli occupation and a volatile political situation. This article argues that the political chaos following the Oslo Agreement of 1993 has led to civil society fragmentation and the marginalisation of certain groups. However, women's traditional involvement within the Palestinian national movement led to their assumption that society would adopt a non-gender biased perspective during elections. Disappointing results led to the formation of a coalition to campaign for a quota system. Now, following its introduction, Palestinian women are faring much better than many of their other Middle Eastern counterparts in terms of political representation. However, although this article points to the importance of affirmative action in triggering increases in women's political participation; the context of persistent insecurity and siege which overshadows their lives means women are unable to wield any real political power and implement the improvements within their communities which they hoped entering politics would allow them to do.

\section{Introduction}

This article examines what it means for women to claim political representation in the highly complex context of Palestine, one characterised by Israeli Occupation and a deep rift over political agendas and means of liberation. Exploring how volatile political and socioeconomic dynamics influence women's agency in politics, it addresses the challenges women who seek to enter politics face; the factors that enable them, and the nature of the processes of mediating different political forces. It argues that while direct political involvement of women in the national struggle was an important medium for women's collective empowerment, the call for affirmative action needs to be analysed, with particular attention to the nuances of its context. In the Palestinian case, where political instability and Occupation violence persist, the call for affirmative action for women might not be the most effective pathway for women's empowerment. This is especially so since the politically chaotic situation has served to fragment women's power and their ability to act as a collective. Moreover, while Palestinian women have historically been politically active and have sought to integrate a concern with issues of gender equality into struggles for national liberation and social emancipation for all, the way in which the quest for more gender equitable political representation has been externally engineered, raises some serious questions with respect to its democratic credentials. The interplay of foreign and local dynamics and their implications for Palestinians will be discussed at length.

\section{Contextual background: politics and agency in disarray}

Affirmative action for women is highly contextual in its dynamics and implications. Quotas might increase the number of women in public office, but the ability of these women to affect a change depends on the stability and dynamics of the political context. In the case of Palestine, the introduction of quotas needs to be set against a backdrop of persistent insecurity.

The Oslo agreement between the Israeli government and the Palestine Liberation Organisation in 1993 triggered an illusionary process of 'state building', without leading to peace or political stability. The Agreement was born, not out of the strength of the local or international positions of the PLO vis-à-vis Israel, but out of the desperation of particular elites in

IDS Bulletin Volume 41 Number 5 September 2010 (c) 2010 The Author. Journal compilation (c) Institute of Development Studies Published by Blackwell Publishing Ltd, 9600 Garsington Road, Oxford OX4 2DQ, UK and 350 Main Street, Malden, MA 02148, USA 
the Diaspora, and it led to what became known as the 'self-rule' areas of the Palestinian

Authority (PA). According to the Agreement, the PA controls its population but does not have true sovereignty, especially rights over land, resources and external security. Bishara has argued that 'autonomy - self rule, is a form of Israeli control in which Palestinians agree to define and police themselves as non-citizens' (quoted in Parker 1999: xii). The Palestinian Authority was given the authority over the self-rule areas for an interim period of five years, heavily dependent on donor aid and tightly constrained by Israeli 'security' measures and sanctions. The

Palestinian economy became the hostage of an Israeli embargo - an economic siege - that has sent unemployment rates soaring to 60 per cent in some refugee camps in Gaza (Usher 1999: 15).

When the Palestinian leadership took power after the Oslo agreement in 1993, the Palestinian leader Yasser Arafat refused to organise new local elections, fearing the takeover of the power by the Islamic movement Hamas, its strong opponent. It seems that Arafat had foreseen the political impasse that might face the Palestinians once Hamas arrived in power. It is important to stress here that elections were requested by the Americans and funders, in an attempt to establish a new basis for political legitimacy in the Palestinian political system, which had been reliant up to that point on what used to be called the 'national consensus' (tawafoq watani in Arabic). National consensus meant that major decisions affecting Palestinian national struggle were taken within the Palestinian Liberation Organization (PLO) structure that involved all Palestinian political groups in the struggle for national liberation. National consensus was based on the mediation of the charismatic character of the historical leader of the PLO Yasser Arafat and his influence on other political groups under the PLO. National consensus was used instead of public elections (Hilal 1999). Excluded from the national consensus were the Islamists and the Palestinian Communist Party, as the latter does not follow the path of military struggle as a path to liberate Palestine.

After his death in August 2004, and under the political pressure of the American administration of Bush, the first local elections were organised in stages that started on December 2004 and ran until December 2005. The sweeping victory of the Islamists in the first Palestinian legislative elections in January 2006 forced the PA to stop the final round of local elections, fearing the control of Hamas of the remaining local councils. Israel and Western governments refused to acknowledge the result of the Palestinian legislative elections. This hampered all attempts to form a national unity government or any form of government with Hamas in power. A wave of assignation, imprisonment and torture targeted the Islamic movements' figures and leaders in Gaza and the West Bank. The Hamas takeover of Gaza led to a total rift between the PA, led by the political organisation Fateh, and the Hamas movement. Thus, the elections came to fragment the Palestinian polity and society and contribute to the marginalisation of social and political movements that used to support women's rights and emancipation.

The rising power of the Islamists posed some challenges to this process. The Islamists called for electing all levels of leadership within the PLO, a request that had been refused by the historical leadership of the PLO chaired by Arafat. Instead, the Islamists asked for a quota that would represent their political weight among the Palestinians, suggesting it should not be less than 40 per cent of members of the National Council, which is considered to be the Palestinian Parliament and which elects the Executive Committee, the highest authority endowed with decision-making power. The Executive Committee was never elected, but again followed the national consensus mechanism. This request was refused. The Islamists used the local (2004-05) and legislative elections (2006) as opportunities to show their power, emerging from the elections in a very favourable position, which did not prove helpful in establishing a new source of legitimacy in the Palestinian context nor in arriving at an alternative national consensus. Islamist participation, for the first time after the Oslo Accord, in the local elections of 2004-05 and the legislative elections of 2006, brought a huge number of women to the vote (PCBS 2008).

The election results led to the division of the Palestinian political system, a division that was backed and supported by the international donor community. This was aggravated by Hamas taking power in Gaza on 15 June 2007, which led 
the Palestinian Authority, based in Ramallah, to renounce the Hamas government as illegal. The political split led to the paralysis of almost all 'state' institutions, whether the legislative council, the judiciary or the executive branch. Thus, parallel 'state' institutions were created to represent the Hamas authority in Gaza and the PLO authority in the West Bank. Consequently, all legal reforms have been suspended and there are severe hindrances to effectuating policies on a national level.

This political split, coupled with the Occupation, has incapacitated existing forms and institutions of governance in Gaza. A total siege imposed by the Israelis has blocked the Hamas government from having access to financial resources, whether of a local or international nature. This has led to the paralysis of almost all local councils that were won by the Islamists. Western donors have refused to fund any project for councils run by the Islamists. The Palestinian Authority has attacked some of the councils that are run by the Islamists, arresting some of their members and replaced members with those loyal to the Palestinian Authority. The persistence of a high level of unemployment as a consequence of the Occupation and the limits this poses on the capacity of the Palestinian labour market to accommodate new entrants, impedes the capacity of local councils to undertake development initiatives. Most of these councils work, if they have the resources, to provide temporary parttime jobs. The spread of checkpoints in the West Bank and the siege on Gaza (air, sea and land) further entrenches poverty, unemployment and economic and political instability.

Before the establishment of the Palestinian Authority, Palestinians in the Occupied Territories used to have a vibrant civil society with very active engagement of political parties, unions, social movements, charitable societies, students' councils and women's organisations. Almost all forms of organisation used to organise regular elections with a high level of participation. With the establishment of the Palestinian Authority, many forms of social organisation were targeted by the Palestinian security forces, especially Islamist organisations. This has led to a noticeable level of de-mobilisation.

It is against this backdrop that the use of affirmative action policies to enhance the proportion of women in political office needs to be understood.

\section{Affirmative action in Palestine: feminist aspirations between past and present realities} Reading the history of Palestinian women's activism teaches us that direct action and involvement in the Palestinian national movement was an important and empowering medium for women's collective action and empowerment. Through their involvement in the national struggle and politics, women constituted themselves as a movement and gained important access to the public space through a troubled relationship with and against their national leadership.

Women's power in the 'revolutionary' era was developed through the women's collective action in the national movement and against its patriarchal structure. Thus, women affirmed themselves through their own activism. From its inception, the PLO was never much concerned with issues of women's empowerment, gender or gender relations (Peteet 1991). The absence of a well worked out commitment places a big burden on the women's movement to articulate and formulate the gender interests of women in their different social positions. Fateh policy has consistently held that struggles other than national liberation, are of a secondary nature, thus denying an intimate relationship between polity and society (Peteet 1991). One of Fateh's leaders, Mounir Shafiq, saw that 'throughout the different phases of the national struggle, women did not separate themselves from the cause of their people' (Mounir Shafiq, cited in AlGhounimi 1981: 201). While Shafiq sees that women's role is crucial in the 'people's war' and objects to those who seek to spare women the 'trouble of taking part in the struggle' (AlGhounimi 1981: 206), he nonetheless maintains that women should not challenge 'traditions' reflected in prevailing gender roles, in particular in caring for their families and children (AlGhounimi 1981: 224).

This vision was contested by women in Samed (Palestine Martyrs Works Society), Fateh and the General Union of Palestinian Women (Mai Sayigh, cited in Al-Ghounimi 1981: 125). Women started to pressure the leadership for a clear position on the gender order. This pressure led to a series of activities and debates, fed by some 
books and papers on women's role in the 'revolution' (Abu Ali 1975; Al-Khalili 1977; Shafiq 1977; Al-Amad 1981). In one of these debates, the head of the Union, Mai Sayigh stressed that:

women in the revolution, and even in the military are still used as a propaganda façade for the political organisation; women are still far from playing a real role in the revolution seen as the preserve of different organisations in political competition and rivalry (Mai Sayigh, cited in Al-Ghounimi 1981: 125).

Influenced by Marxist women, the head of the Union went on to articulate the three forms of the oppression of women as 'the enslavement of women to men; to the society and to the Occupation' (Essam Abdel Hadi, cited AlGhounimi 1981: 123).

The 'progressive' ideology of the Marxist-Leninist organisations in the PLO made them more receptive to women's pressures, but did not alter their classical Marxist stand on gender: women are oppressed but first the national and class struggle must rid the people of colonialism and then of capitalist exploitation. They encouraged women to play an active role, equal to that of men, in these struggles. All avoided confrontation with the prevailing gender order. Marxists, like most Arab male leftistnationalists, often strongly distinguished between women's liberation in the public sphere and their sexual/bodily freedom, the latter being viewed as superficial, bourgeois and individualistic (Hasso 1997). The decline in secular left ideology and a decline in women's power and activism in the national movement reduced the achievements women's movements might realise. This is a conjuncture where the Islamists' power started to grow and the secular nationalists' power went into decline after 1993.

The Authority has neither gender vision nor a political project for social change. Yet being donor dependent, weak and fragmented, the Authority has shown some positive reactions to pressure from women's collective action. The quota is one outcome.

\section{Affirmative action in Palestine}

Affirmative action in Palestine has been introduced on two levels, national and local. On a national level, a policy of introducing 20 per cent of seats for women has been instituted. The first legislative elections took place in 1996 with no quota for women. Five women out of 88 members won Parliament seats, representing a mere 5.6 per cent. Activist women and leaders had refused to call for a quota, thinking that they could gain more seats than the quota might give them. They had assumed that, based on their pivotal role in national liberation struggles and their participation in national politics, people would vote for women equally as men.

After this defeat, women started to lobby to introduce a quota into electoral law. Women formed an impressive coalition and organised a national campaign aimed at securing a quota for women. The coalition was led by the General Union of Palestinian Women, with active participation from other women's organisations such as Women's Affairs Technical Committee, The Palestinian Initiative for the Promotion of Global Dialogue and Democracy, Miftah, ${ }^{1}$ and the Working Women Society. What triggered the coalition was women's lack of faith in their political parties and groups to field women or to support their candidature. The Islamists were not part of the coalition. They were not asked to join and they did not seek to join it. The coalition's leadership by renowned Fateh figure Khadija Habashneh - who was also part of the old PLO structure - gave women easy access to top level leadership and to the media. Women proved influential in lobbying politicians to legislate for a quota.

The quota for local councils was introduced in stages. At the beginning in 1998, the minister of local government asked to add one woman at least to each council. By 2000, the number of women in local councils reached 63 out of 3,535 representing 1.7 per cent. The district system with no quota for women proved to be hostile to women's participation, even while conforming to a system of full proportional representation - a system that has proven conducive to increased levels of representation of women in other contexts (see Ballington, this IDS Bulletin). In 2005, the local election law was amended to introduce a 20 per cent quota for women.

In the local elections that followed, a significant increase in women's representation was observed: 537 women out of 2,732 were represented in local councils, representing 19 per 
cent. Women made up 30 per cent of candidates and 50 per cent participated in voting. Thus, the introduction of a quota was crucial to increase the number of women in local councils. Yet the levels of political representation by women continue to disappoint Palestinian activists, who had hoped for more progress towards parity, given the significance of women's role in the national struggle. Efforts are underway to press for quotas to be applied to other parts of the electoral system, such as the district elections in which there is currently no quota, historical hostility towards women's participation and very low levels of female representation.

\section{Women contesting elections in Palestine: pathways to political office}

In local councils, where women were known at the local level and active in public life in roles such as school headmistresses, teachers, and social activists, they fared well in elections, while those who had been chosen by their parties to fill the electoral lists were, to some extent, marginalised by their political parties or the local councils after elections. Kinship played a controversial role; in some places kinship ties and support played a major role in promoting women, in other instances, where male members were determined to run, family ties played a negative role in pressuring women not to run. In general, in urban centres, party support was crucial for women, and in villages and small towns, both party and family support were important for women's participation.

With the weakening of political parties after the Oslo agreement, especially the leftist parties, it is to be expected that family and kinship relations would play a more important role in elections, beside the ruling party Fateh with its security forces apparatuses. Historically speaking, leftist parties were in the lead for women's political participation, followed by Fateh, and they were all part of the PLO. Hamas followed the same path, since the quota encouraged them to field women to increase their own political representation and their political influence: Fateh also took this stand (Jad 2008) but this stand does not stem from the belief in a well spelled-out feminist agenda. However, women used this chance by organising themselves and shifting the political agenda to their own benefit to ask for more power and 'real' representation. After the political split between the West Bank and Gaza, for example, the Hamas government in Gaza did not cancel the Women's Affairs Ministry. Women in Hamas managed to run the Ministry and shift it towards an agenda to defend women's rights, using it to call for their 'development'.

Women's movements and NGOs played an important technical role in training and equipping women for political office. The women's coalition of the Women's Affairs Technical Committee and the Miftah were both crucial in training women candidates on how to run an election campaign, how to fundraise for it, how to mobilise support, how to mobilise a constituency, how to deal with the media, how to understand the role of the local councils, and about the election law and the quota. Both organisations worked on issues related to leadership skills and self-assertiveness. But once women were in political office, the role of NGOs in supporting them and equipping them for their new role was minimal. While NGOs could be of support to women candidates, this role cannot substitute political parties' role in supporting women politicians. NGOs, relying on a limited project cycle for funding, cannot sustain their work for women's support in political office. The Ministry of Local Government, in cooperation with women's NGOs, are working to bridge the gap in reaching for women candidates once they are in office. A call to establish a national coordinating committee for all women in local councils is one of the instruments used to reach women after they have been elected. Whether this new instrument will reach all women irrespective of their political affiliation is a challenge to be seen in the future.

On the whole, women's performance in elections relies on their political context. A woman candidate in a council that is well supported by donor funding is differently located than a woman from the Islamist movement located in a remote village with no support from the Ministry of Local Government nor the donor community. Other factors could play a role in evaluating the performance of women, such as the level of education, leadership skills, political training, the support of her family and husband, and the respect and trust of the local community. It can be summarised that enabling political environment, party support, family support and personal qualities and skills are major factors for success. 
In order to shed some light on women's activism in politics and their pathways to political office, four mini-profiles follow: Aisha Yassine from Assirah Ashamalieh, Laila Shreime from Jenin, Sireen Abu Muaisse from Al Lemghaire and Hanan Abu Mashaikh from Al Maghazi in Gaza:

1 Aisha Yassine: Assirah Ashamalieh (North). Aisha finished high school and worked for a long time as an art teacher in many Palestinian communities. Married with children, Aisha ran for election as an independent and refused to be part of any party list. Her list [of mainly independents] got the first four seats with no quota. She attributes her success to her social and community work before election. She quickly proved herself in the local council and got her family and her community support. She believes that the husband's support is very crucial to a woman's success. She reflects: 'Once I put my feet in the council for the first time, I felt intimidated, but quickly I learned and put myself in many committees. I helped a lot of women to get good training, good services and to apply to many projects offered by the local council' (Mohamad 2008: 78). Aisha received some training before the election from women and from civil society organisations. She is considering fielding herself again for the next round of local elections.

2 Laila Shreime: Jenin (North). Married with children, her husband and children did not encourage her to nominate herself in the local council, but encouraged her later on to be elected. Her party (Fateh) encouraged her to nominate herself. She used to be very active in her community, working for many civil society organisations and is an active unionist. She commented, 'When I started my first days in the local council, I told the Hamas leader and the other members "gone are the days of the political rivalry, we are all now here to serve our city, Jenin"” (Mohamad 2008: 69). She was well respected and welcomed by all other members. She is active in many committees in the council: the coordinator for the cultural committee, the social committee, and the women's committee, a member in the external relations committee and a member in the human resource committee. She complains about the siege that was enforced on their council because it is headed by
Hamas, 'I appeal to our President and to the whole world to work to lift the political siege imposed on our local councils, we want to serve our people, we have many important projects we work hard to implement like a public slaughter house, three girls' schools, a garden, sewage system. Besides we have more than 1,250 employees, who all need support'. She is considering fielding herself again in the coming local elections.

3 Sireen Abu Muaisse: Al Lemghaire (North). Sireen finished high school and was active in her community and a member of the General Union of Palestinian Women. Her husband and family encouraged her to run for election. The main support for her came from the former head of the local council who was from her family, but his support came because she is educated. In her first days in the council, she was afraid and felt insecure, but later on it became 'normal'. She does not think to run for the head of the council: 'This is too much, too far to reach and men could be better in this post, they could achieve better since they can reach further places than women. Besides with the mentality of our men this might not be easy, if our men change I will change too' (Mohamad 2008: 91). Sireen and the other female members who joined the local council were able to get approval from Care International to build 25 water wells: 'When we got this project, men attributed this to themselves, but my colleague refused and insisted on claiming our success, she went and put on the mosque's door a paper congratulating us by name for securing the construction of the 25 water wells' (Mohamad 2008: 91). Sireen's experience in the council taught her 'to call upon women to consult with their daughters, to give them freedom, to trust them, they have to have strong characters, a strong character for a girl is equally important as education, this is what I learned from my experience in the council' (Mohamad 2008: 92).

4 Hanan Abu Mashaikh: Al Maghazi (Gaza). Hanan did not consider running for public office but her party and her husband persuaded her, and her family and community gave her strong support. She had some training on the local election, which was very useful in giving her self-confidence and some important information on her role as council member. She organised a successful campaign, relying 
on home visits and personal contacts, 'to replace the absence of media coverage, but the campaign was very tiring that I lost my eight month pregnancy' (Mohamad 2008: 169). Her loss was compensated in part by her victory: 'it was a big day and I promised my voters that I will never let them down, I had high hopes and was full [of] energy to do many things to change women's lives, but the siege on Gaza crippled us from doing anything' (Mohamad 2008: 170).

The above cases show that the quota was crucial in triggering momentum for some women to enter public office. Whether married or unmarried, family support was an important factor in enabling these women to embark on their political careers. Political parties, too, were an important medium. Political parties 'chose' some candidates and persuaded them to run for elections, some of whom - particularly for women in Hamas - might be difficult to imagine as candidates in public elections without the quota. People's trust through social activism was another important factor behind their success. However, while the quota created a conducive environment for these women to be in decision-making positions, the words of Laila Shreime from Jenin shows the dilemma of women 'empowered' by affirmative action: 'I appeal to you, lift the political siege imposed on our local councils, we want to serve our people' (Mohamad 2008: 72).

Affirmative action brought an important number of women to public office for the first time in the history of women's political activism, however, the political chaos and the enduring Occupation led to the marginalisation of these voices to effectuate political change amid the decaying of the Palestinian Authority and the rift and fragmentation of all forms of social organisation, including women's power.

\section{Conclusion}

Having secured 20 per cent of total seats in parliament and local councils, Palestinian women are faring far better in terms of participation in political institutions than many of their MiddleEastern counterparts, who are neither living in conditions of Occupation nor under a government in extreme disarray. Even so, the current situation falls short of Palestinian women's expectations. The initial focus of women's struggle was not the quota. Guided by the belief that society will assume a non gender-biased perspective when voting, because women have been politically active as partners in a liberation struggle, the Palestinian women's movement had thought that women's full political representation would be compromised rather than enhanced with a quota. Yet the disappointing results in the parliamentary elections suggested otherwise: the coalition for a quota was in a sense a call for recognition of women's political voice and presence, one that society had failed to make. The low political representation of women in district level elections where a quota was not implemented, as opposed to local council elections where it was instituted via a proportional party list system, illustrates the importance of affirmative action, and an acute focus on the minutest details of its implementation. The fact that the Islamists did not participate in the coalition in favour of a quota did not stop them from utilising the quota to field female members who would then increase the political force's presence and clout. How far women's and men's political participation will continue in the political processes of the upcoming elections remains to be seen.

The quota was enacted in a very disabling, fragmented and disempowering context. The election process proved to be highly divisive, and external intervention did not help. The deep polarisation between the PLO and Hamas had an impact on women's ability to overcome political and ideological differences and work towards a common agenda. The divisions in political and civil society have continued to undermine, making public office functional, for both men and women. Furthermore, the Occupation and Siege have meant that in some contexts, there is no system of governance in place. Hence, we are left with an ironic situation in which the quota has brought women into a political office that is in effect dissolved of any real political power to implement policies and lead change. In such a context, the question becomes: What kind of political leadership can women exercise and how, if the mechanisms of enforcing decisions or initiating policies is stalled? Much negotiation will be required in the next phase: the district quota; the divisions in political society; the role of civil society in the political process; the differences in the women's agendas of Hamas and the PLO, as well as finding the capacity to make political agency meaningful. 


\section{Note}

1 The Palestinian Initiative for the Promotion of Global Dialogue and Democracy, Miftah, was established in 1998 as a non-governmental non-partisan Jerusalem-based institution

\section{References}

Abu Ali, Khadija (1975) Mokademat Hawla Waki' Al-marah wa Tajrobateha fi Al-thawra Alfalastineyya [Introduction to Women's Reality and Their Experience in the Palestinian Revolution], Beirut: General Union of Palestinian Women (GUPW)

Al-Amad, Salwa (1981) 'Molahathat Hawla Waqi'a Al-marah fil Thawra Al-falastineyya' [Observations on Women's Status in the Palestinian Revolution], Sho'oun Falastineyya [Palestine Affairs] 113: 9-20

Al-Ghounimi, Zeinab (1981) 'Halaqa Derasseya Hawla Awda' Al-marah Al-falastineyya' [A Workshop on the Status of Palestinian Women], Beirut, 23-25 March, Sho'oun Falastineyya [Palestine Affairs] 114: 123-8

Al-Khalili, Ghazi (1977) Al-marah Al-falastineyya Wal-thawra [Palestinian Woman and the Revolution], Beirut: Marqaz Al-abhath Walderassat Al-falastineyya [Institute of Palestine Studies]

Hasso, Frances Susan (1997) 'Paradoxes of Gender/Politics: Nationalism, Feminism, and Modernity in Contemporary Palestine', $\mathrm{PhD}$ thesis, University of Michigan

Hilal, Jamil (1999) Al-mojtam'Al-falastini wa Iskaleyat Al-dimocrateya [Palestinian Society and Democracy Problems], Nablus: Centre for Palestine Research and Studies dedicated to fostering democracy and good governance within Palestinian society. www.webgaza.net/palestine/ngo_profiles/ Miftah.htm (accessed 2 July 2010).

Jad, Islah (2008) Nissa 'Ala Taqato'a Torok [Women at the Crossroads], The Palestinian Women's Movement between Nationalism, Secularism and Islamism, Ramallah, Palestine:

MUWATIN, The Palestinian Institute for the Study of Democracy

Mohamad, Zakaria (2008) 'Reyah al Taghieer' [Winds of Change], Nissa min baladi series [Women from my country series], Ramallah, Palestine: Women's Affairs Technical Committee

Parker, Christopher (1999) Resignation or Revolt? Socio-Political Development and the Challenges of Peace in Palestine, London: I.B. Tauris

PCBS (2008) Al Mara wal Rajol fi Falstine, Qaddaya wa Ihsaat [Woman and Man in Palestine, Issues and Statistics], Ramallah, Palestine: Palestinian Central Bureau of Statistics, December

Peteet, Julie (1991) Gender in Crisis: Women and the Palestinian Resistance Movement, New York: Columbia University Press

Shafiq, Mounir (1977) 'Mawdo'at Hawla Nidal Almarah' [Issues on Women's Struggle], Sho'oun Falastineyya [Palestine Affairs] 62: 200-27

Usher, Graham (1999) Dispatches from Palestine: The Rise and Fall of the Oslo Peace Process, London: Pluto Press 